\title{
Kırgızistan Enerji Tüketiminin Ayrıştırma Yöntemiyle Analizi (2002-2011)
}

\author{
Decomposition Methods for the Analysis of Energy Consumption in Kyrgyzstan (2002-2011)
}

\author{
Aziz BOSTAN', Alper YILMAZ², G. Afşin RAVANOĞLU³
}

\begin{abstract}
ÖZET
Bu çalışma 2002-2011 yılları arasında Kırgızistan ekonomisi için sektörel enerji tüketimini ayrıştırma yöntemiyle analiz etmeyi amaçlamaktadır. Çalışmanın sonuçlarına göre sektörel enerji tüketiminin çıktı ve yapısal etki nedeniyle arttığı, yoğunluk etkisi nedeniyle düştüğü görülür. Ayrıca diğer iki etkiye göre çıtı etkisi sektörel enerji tüketimi üzerinde en güçlü etkiye sahiptir. Sektörel enerji tüketimi, üretim artışı ile daha çok ilşkili olduğu için, Kırgızistan ekonomisinde 2000 yılından sonra görülen hızIı ekonomik büyüme, çıktı etkisini enerji tüketimindeki artışın en önemli faktörü haline getirmiştir. Yapısal etki, milli gelir içinde tarım sektörünün payının azalmasına ve sanayi sektörünün payının artmasına bağıı olarak enerji tüketimindeki değişime arttırıcı yönde etki yapmıştır. Yoğunluk etkisi ise diğer iki etkinin tersine, ekonomide teknolojik gelişim bakımından son yıllarda görülen iyilştirmeler ve dışa açılma gibi nedenlerle enerji tüketimini düşürücü yönde etki yapmıştır.
\end{abstract}

Anahtar Kelimeler: Kırgızistan, enerji sektörü, enerji tüketimi,

\section{GíRiş}

Kırgızistan'ın sosyo ekonomik gelişimi Sovyet dönemi, geçiş süreci ve serbest piyasa dönemi olarak üçe ayrılabilir. Sovyet döneminde ülke blok içinde genel olarak uygulanan ihtisaslaşma sistemi içinde kendine biçilen role göre ekonomisinde uzmanlaşmıştır. Bilindiği gibi Sovyet ekonomisi merkezi planlamaya dayalı kumanda ekonomisidir. Üretim devlet tarafından tek elden planlanır ve üretimin amacı kar veya satışları arttırmak değil halkın ihtiyaçlarının karşılanmasıdır. Hangi malın ne kadar üretileceğine, hangi fiyattan satılacağına ve hangi kaynakların harekete geçirileceğine sıkı bir disiplin içinde hep devlet planlama teşkilatı (Gosplan) karar verir. Bu çerçevede maliyetleri düşürmek veya verimliliği arttırmak ikinci plandadır (Mazat ve Serrano, 2009:3). İște bugünkü Kırgızistan ekonomisindeki pek çok sorunun kaynağı bu merkezi planlama anlayışı olmuştur. Planlamanın gereği olarak blok içindeki her ülkeye bir rol verilmiş ve o ülke ekonomisinin ihtisaslaşması o rol çerçevesinde olmuştur. Verilen rol ise o ülkenin coğrafi özelliklerine, kültürel ve ekonomik yapılarına ve eğitim

\begin{abstract}
This paper aims to investigate sectorial (service, industry and agriculture)energy consumption in Kyrgyzstan economy for the 20025-2011 periods. The results indicate that the primary energy consumption has been increased as a result of production and structural effect but decreased as for intensity effect. Also production effect has the strongest influence on primary energy consumption in accordance with other two effects. It has been clearly seen that sectoral energy consumption increase with production closely. Rise in primary energy consumption during 2002-2011 periods was mostly due to rise in production. Similarly, structure effect has been come to conclusion as positive correlation with primary energy consumption because of increase in relative share of energy intensive sectors (especially industry) in national income. However results for intensity effect shows that till 2009, it decreased primary energy consumption, but after 2009, there has been moderate decrease in energy intensity in Kyrgyzstan economy.
\end{abstract}

Keywords: Kyrgyzstan, energy sector, energy consumption

seviyesine bakılarak belirlenmiştir. Bu sistem ülkeleri birbirine daha bağımlı hale getirmiş, hiçbir ekonomi tek başına kendi kendine yeterli olamayacak şekilde yönlendirilmiştir. Kırgızistan ekonomisine biçilen rol ise tarım ve hayvancılık olmuştur. Sonuçta ülke gün gelmiş 3 milyonluk nüfusuna karşın 15 milyon hayvan varlığının olduğu bir ülke olmuştur (Ramazanoğlu ve Acar, 2003:389).

Geçiş süreci ise serbest piyasa ekonomisinin kurum ve kuruluşları ile yetersiz olması, ülkenin hukuk sisteminin gelişmemiş olması ve demokratik bilincin zayıf olması gibi nedenlerle bocalama içinde geçmiş, 1991- 1997 arasında ekonomi ortalama \%6,5 küçülmüştür. 1990 yılı 100 kabul edildiğinde reel GSYIH, 1995 sonunda 50,6'ya düşmüştür. SSCB'den kopmalarla birlikte eski yapı içinde birbirlerini tamalayan, tek başına yeterlilikten uzak ekonomiler, bağımsızıklarını kazanmalarıyla kendilerini birden küresel sistemin rekabet ve acımasız kurallarının işleyiş̧i içinde bulmuşlar, birbirlerine bağımlı kurulmuş üretim ve tüketim yapılarının bir anda bozulmasıyla üretim hızla gerilemiş ve şiddetli makroekonomik dengezislikler

\footnotetext{
${ }^{1}$ Yrd. Doç. Dr., Kırgızistan Türkiye Manas Üniversitesi, İktisadi ve İdari Bilimler Fakültesi, İktisat Bölümü, azbostan@hotmail.com

${ }^{2}$ Yrd. Doç. Dr., Adnan Menderes Üniversitesi, Söke İşletme Fakültesi, Uluslararası Ticaret ve İşletmecilik Bölümü, alper.yilmaz@adu.edu.tr

${ }^{3}$ Kırgızistan Türkiye Manas Üniversitesi, İktisadi ve İdari Bilimler Fakültesi, İktisat Bölümü, afsinrevan@hotmail.com
} 
yaşanmıştır. Ayrıca bağımsızlıkla birlikte farklı ülkelerin kalifiye elemanlarının kendi ülkelerine dönmesiyle sanayi ve hizmetler sektöründe kalifiye işgücü açığı üretim düşüşlerine neden olmuştur (Egeli ve Emsen, 2002:106-112). Diğer yandan Yöneticiler otoriter davranmış, halkın ihtiyaçlarını değil kendi iktidarlarının selahiyetini birinci plana almışlardır. Dolayısıyla bu dönemde yoksulluk artmış, gelir dağılımı bozulmuş, kuzey güney ayrımı belirginleşmiştir (Kyrgyzstan Country Report, 2012).

Bugünkü anlamda modern kırgızistan'ın şekillen- diği süreç geçiş süreci sonrası dönemdir. Bu dönemde soyo-ekonomik anlamdaki gelişmelerin temellei atılmıştır. İlk olarak ülke nüfusu 1994-2011 arası 4,5 milyondan 5,5 milyona çıkmıştır. Nüfus artış hızı 2011 itibariyle \%1,1'dir. Toplumsal olarak boyların varlığını hala sürdürdüğü bir ülke olan Kırgızistan'da boylar iki büyük federasyon şeklinde örgütlenmişlerdir. Issık gölünün güneyinde yerleşmiş olan Tagay Boyu, siyasi ve entelektüel elitin ait olduğu boy olarak bilinmektedir. Toplumun bu şekilde örgütlenmesi zamanında SSCB tarafından da değiştirilmeye çalışılmamış; aksine kontrol mekanizması olarak kullanılmıştır.

Tablo 1: Milli Gelir

\begin{tabular}{|c|c|c|c|c|c|c|c|c|c|c|c|}
\hline \multicolumn{2}{|c|}{$\begin{array}{l}\text { Sbt. Fiy. GDP } \\
\text { (Milyon Som) }\end{array}$} & 2002 & 2003 & 2004 & 2005 & 2006 & 2007 & 2008 & 2009 & 2010 & 2011 \\
\hline \multicolumn{2}{|c|}{ Genel Toplam } & $73,870.5$ & $80,665.2$ & $89,765.1$ & $94,185.1$ & $104,030.0$ & $123,521.9$ & $153,819.4$ & $193,417.9$ & $200,274.0$ & $232,892.9$ \\
\hline \multicolumn{2}{|l|}{ Tarım } & $26,311.7$ & $26,757.6$ & $29,356.6$ & $27,039.5$ & $29,226.5$ & $33,159.7$ & $38,469.4$ & $47,114.9$ & $36,773.4$ & $39,328.5$ \\
\hline \multirow{4}{*}{ Sanayi } & Madencilik & 383.4 & 366.2 & 505.1 & 570.5 & 514.4 & 473.0 & 702.3 & $1,079.0$ & $1,033.3$ & $1,725.3$ \\
\hline & İmalat & $11,615.9$ & $11,589.0$ & $11,378.5$ & $12,026.0$ & $11,133.6$ & $13,302.4$ & $17,060.2$ & $22,538.2$ & $31,874.0$ & $41,018.6$ \\
\hline & Elektrik Gaz & $3,214.9$ & $3,629.8$ & $3,033.4$ & $3,125.1$ & $3,869.7$ & $4,234.0$ & $3,594.0$ & $2,603.1$ & $4,859.8$ & $8,381.7$ \\
\hline & Sanayi Toplam & $15,214.2$ & $15,585.0$ & $14,917.0$ & $15,721.6$ & $15,517.7$ & $18,009.4$ & $21,356.5$ & $26,220.3$ & $37,767.1$ & $51,125.6$ \\
\hline \multirow{9}{*}{ Hizmetler } & İnşaat & $2,819.9$ & $2,522.7$ & $2,578.7$ & $2,727.0$ & $3,247.0$ & $4,024.5$ & $5,618.5$ & $12,062.3$ & $10,994.7$ & $11,965.6$ \\
\hline & Ticaret & $9,781.6$ & $12,098.8$ & $15,101.7$ & $16,893.4$ & $20,681.5$ & $23,163.0$ & $27,878.4$ & $31,422.6$ & $31,982.0$ & $37,645.5$ \\
\hline & Ulaştırma & $3,130.5$ & $4,190.3$ & $5,251.4$ & $6,787.7$ & $7,249.4$ & $9,947.5$ & $13,841.0$ & $15,575.0$ & $18,420.7$ & $20,748.7$ \\
\hline & Finans & 838.8 & $1,252.4$ & $1,322.3$ & $1,913.9$ & $2,689.6$ & $3,229.0$ & $5,090.6$ & $7,416.1$ & $7,743.2$ & $9,185.3$ \\
\hline & Kamu Yönetimi & $3,821.1$ & $3,994.3$ & $4,057.8$ & $4,385.8$ & $4,648.5$ & $5,145.1$ & $6,316.1$ & $8,880.3$ & $10,724.7$ & $13,083.9$ \\
\hline & Diğer & $7,127.4$ & $7,959.0$ & $9,647.7$ & $10,513.3$ & $11,585.5$ & $13,991.4$ & $18,406.1$ & $25,073.4$ & $30,260.5$ & $34,004.9$ \\
\hline & Finansal aracılık & -531.0 & -710.1 & -802.6 & $-1,331.6$ & $-2,090.9$ & $-2,556.9$ & $-3,924.3$ & $-5,756.4$ & $-6,434.3$ & $-7,794.7$ \\
\hline & Vergiler & $5,356.3$ & $7,015.2$ & $8,334.3$ & $9,534.5$ & $11,275.2$ & $15,409.2$ & $20,767.1$ & $25,409.4$ & $22,042.0$ & $23,869.6$ \\
\hline & Hizmetler Top. & $32,344.6$ & $38,322.6$ & $45,491.3$ & $51,424.0$ & $59,285.8$ & $72,352.8$ & $93,993.5$ & $120,082.7$ & $125,733.5$ & $142,708.8$ \\
\hline
\end{tabular}

(Kaynak: Asian Development Bank Fact Sheet 2012)

Ekonominin temeli hala tarım ve doğal kaynaklara bağlı olan ülkede en çok pamuk ve tütün yetiştirilmekte, altın madeni çıkarılmakta ve ihraç edilmektedir. Kırgızistan'ın metalurji sektöründe üretilen ürünlerin neredeyse tamamı ihraç edilmektedir. Ülke dünyada onuncu büyük altın üreticisi ve ihracatçısıdır. Endüstriyel alanda ise altın, cıva, uranyum, doğal gaz ve elektrik enerjisi ihraç etmektedir. Geçiş sürecinde tarımın istihdamdaki payı \%41'den \%31'e gerilemiş, sanayinin payı \%19'dan \%21'e çıkmıştır. Geçiş süreci ile ülkede liberal reformlar uygulanmış, konvertibilite ve faiz oranları serbestleştirilmiş, özelleştirmeler hızlandırılmıştır. Bu kapsamda sabit fiyatlarla Gayri Safi Yutriçi Hâsılası 2002'de 73.870 milyon som'dan 2011 'de 232.892 milyon som'a çıkmıştır. Bu verilere göre ülkede kişi başına düşen milli gelir 42.344 som (yaklaşık 1075 usd) dur.
Aşağıdaki tabloda ise milli gelirin sektörel dağılımı verilmektedir. Görüldüğü gibi tarımın payı \%36'dan $\% 17$ 'ye düşmüş, sanayinin payı hemen hemen aynı kalmış ve hizmetler sektörünün payı \%44'ten \%61'e çıkmıştır. Ekonominin serbest piyasa ekonomisine dönüşümü sürecinde tarım sektörünün payı azalması, hizmetler sektörünün payının artması beklenir. Sanayi sektöründe önce görülen azalma kumtor altın madeninde 2002 yılında meydana gelen kazadır. Kazadan sonra yaşanan toparlanma ve altın fiyatlarının dünya piyasalarında artmasıyla birlikte sanayinin milli gelir içindeki payı 2006 yılında \%15'ten 2011 yılında $\% 22$ 'ye çıkmıştır. Bilindiği gibi madencilik sektörünün özellikle de altın madenciliğinin 2011 itibariyle tüm sanayi içindeki payı \%3,3'tür. 
Tablo 2: Milli Gelirin Sektörel Dağılımı (\%)

\begin{tabular}{|l|c|c|c|c|c|c|c|c|c|c|}
\hline Sektör & 2002 & 2003 & 2004 & 2005 & 2006 & 2007 & 2008 & 2009 & 2010 & 2011 \\
\hline Tarım & 36 & 33 & 33 & 29 & 28 & 27 & 25 & 24 & 18 & 17 \\
\hline Sanayi & 21 & 19 & 17 & 17 & 15 & 15 & 14 & 14 & 19 & 22 \\
\hline Hizmetler & 44 & 48 & 51 & 55 & 57 & 59 & 61 & 62 & 63 & 61 \\
\hline
\end{tabular}

( Kaynak: Asian Development Bank Fact Sheet 2012)

Genel olarak 1999 yılından sonra büyüme daha çok tarım ve altın madeni sektörüne dayalı olmuştur. Sanayi sektörü toplam üretiminde maden ve maden ürünlerinin işlenmesi faaliyetlerindeki işletmelerin payı $\% 47$ 'dir. Fakat diğer Türk cumhuriyetlerinde olduğu gibi (Kazakistan-Azerbaycan/petrol-doğal gaz, Özbekistan/Pamuk ve Türkmenistan/Doğal Gaz gibi) ülke belli bir sektöre aşırı bağlanarak risk almaktadır. Kumtor madenindeki altın rezervleri tükenmektedir ve ülke ekonomisinin tek bir altın madenine bu derece bağımlı olması ciddi sıkıntılar yaratmaktadır. Bu yüzden Kırgızistan'ın acil olarak sanayinin sektörel çeşitlendirilmesine yönelik yeni politikalar uygulamaya başlaması gerekmektedir. İşsizlik oranın \%20 olduğu ülkede nüfusun \%31,7ısi yoksulluk sınırının altında yaşamaktadır. GINI katsayısı 33,5'tir. Ülkedeki enflasyon oranı da 2011 verilerine göre $\% 16$ 'dır. Kayıt dışı ekonomi büyük bir problemdir. Ülke aşırı dış borcu sebebiyle Dünya Bankası ve IMF tarafından yürütülen Aşırı Borçlu Fakir Ülkeler (HIPC) programına 2006 yılında başvurarak 1 milyar dolarlık dış borcunun silinmesini düşünmüş ancak bunun itibar kaybına neden olacağı gerekçesiyle vazgeçmiştir (DEIK, 2012).

Kırgızistan'da enerji sektörü, her ne kadar fosil tabanlı yakıtlar bakımından komşuları kadar zengin olmasa da, sahip olduğu hidrolik potansiyel sayesinde önemli bir yere sahiptir. Ülkede elektrik üretimi ağırlıklı olarak hidroelektrik santrallerinde gerçekleştirilir ve büyük bir potansiyele sahiptir. Ülke hidroelektrik kaynaklarının genişliği bakımından Rusya ve Tacikistan'ın ardından BDT ülkeleri arasında üçüncü sırada yer almaktadır. Tien Shan dağlarındaki buzulların erimesiyle yıllık 55,000 gigawatt saatlik bir potansiyel oluştuğu tahmin edilmektedir. Bu potansiyelin yılda yalnızca 3 Gigawatt saatlik bölümünü kullanılmaktadır. Hem büyüyen Kırgız ekonomisi hem de komşu ülke Çin'in enerji açığı göz önünde bulundurulduğunda sektöre daha fazla yatırım yapılmalıdır. Nitekim devletin hidroelektrik santralleri kurma hususunda yabancı yatırımdan faydalanacak şekilde çeşitli çalışmaları ve projeleri gündemdedir. Öncelikle Kambar'da bulunan iki santralin özelleştirilerek faaliyete sokulması projesi mevcuttur. Bu amaçla Rusya ve Kazakistan ile fizibilite çalışmaları yürütülmektedir. Narın nehri üzerindeki Toktogul Hidroelektrik Santrali tek başına tüm ülkenin enerji ve ısıtma ihtiyacını karşılayacak kapasiteye sahiptir. Bu santral yılda yaklaşık 1.5 milyar kWh elektrik üretmektedir.

Ülkede elektrik enerjisinin yanında doğal gaz tüketimi, yıllara göre azalma gösterse de önemli yer tutmaktadır. Çünkü elektrik enerjisi üretim, iletim ve dağıtım alt yapısı sovyet döneminden kalma eski teknolojiye dyanmakta ve yenileme çalışmaları devam etmektedir. 2011 yılında yapılan denetimlerde Kırgızistan'da 18.000 elektrik kesintisi yaşandığı tespit edilmiştir. Örneğin 2012 yılında Kazakistan'dan gelen doğal gaz akışında yaşanan kesilme nedeniyle tüketiciler elektrik enerjisine yüklenince trafolarda ve dağıtım noktalarında arızalar meydana gelmiştir. Dolayısıyla sektörde yatırım ihtiyacı fazladır.

Kırgız Cumhuriyetinde sınırlı miktarda petrol ve doğal gaz rezervi bulunmaktadır. Yılda 80,000 ton petrol elde edilebilmekte olup, iç talebin \% 12'sini karşılanmaktadır. Ülkede boru hattı sisteminin de yetersizliği söz konusudur. Hali hazırdaki 367 kilometre uzunluğunda doğal gaz hattı ve $13 \mathrm{~km}$ uzunluğunda petrol hattı bulunmaktadır. 2007 yılının sonunda Rus Gazprom şirketine 2 doğalgaz yatağının keşfi için lisans verilmiştir. Söz konusu yataklar ülkenin güneyinde bulunan Kuugart ve Maylısuu-4 (Celalabat) kaynaklarıdır (DEIK, Kırgızistan Ülke Bülteni, 2012). Elektrik enerjisinde yeni yatırımlara ve yeni fosil tabanlı yakıt rezervleri bulma çalışmalarına karşılık ülkede büyüyen ekonomiye ve artan nüfusa bağlı olarak ithal enerji gereksinimi artmaktadır. 


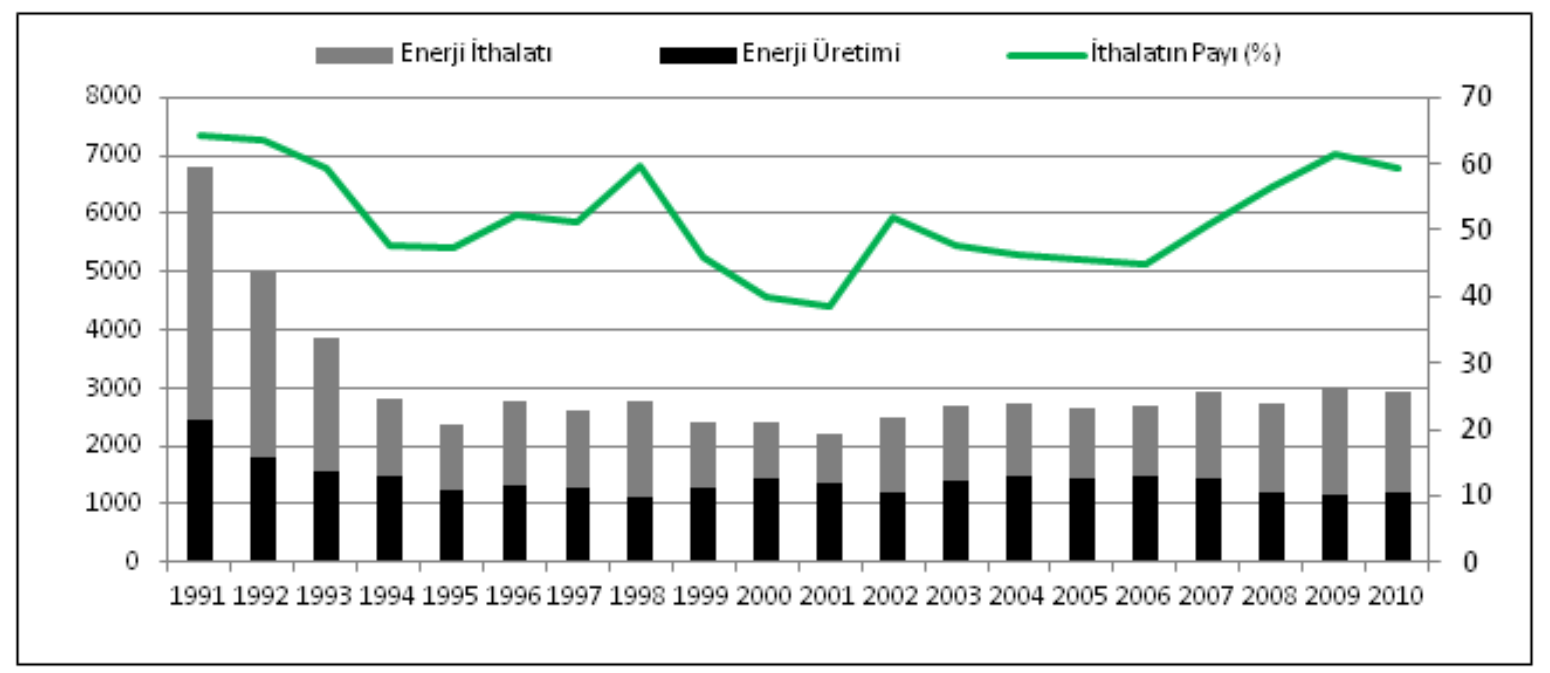

Şekil 1: Enerji Tüketimi ve İthal Enerjini Payı (Btep, \%)

Şekilde görüldüğü gibi bağımsızığının ilk yıllarında Sovyetler'den gelen enerji akışının kesilmesiyle yerli ihtiyacın karşılanabilmesi için 1991 yılında 4,3 Mtep'lik enerji ithal edilmiştir. Izleyen yıllarda ekonomide serbest piyasa düzenine geçişin ve birbirine bağlımlı yapının dışına çıkışın ilk şoklarını atlattıktan sonra, yerli enerji üretimini artımış ve toplam talebi karşılama oranı artmıştır. 2000 yılından sonra ise ekonomik büyümenin ortalama \%4 civarında istikrara oturmasıyla enerji itiyacı artmış ve buna bağlı olarak ithal enerjinin payı 2000 yılında \%39'dan 2010 yılında \%59'a çıkmıştır.

\section{LITERATÜR TARAMASI}

İçinde ve sürekli etkileşim halinde olduğumuz sosyal ve ekonomik çevre zamandan zamana sürekli değişmektedir. Meydana gelen değişikliklerin gerekliliklerine ayak uydurabilmek için yeni politikalar ve yeni değerlendirme yöntemleri geliştirmek zorundayız. Bu da çevremizde sosyal ve ekonomik alanda meydana gelen değişikliklerin altında yatan nedenlerin neler olduğunu bilmemizi gerektirir. Ekonomik, çevresel ve diğer sosyo-ekonomik göstergelerdeki değişiklikleri analiz edip anlayabilmek için bu değişikliklere neden olan faktörleri ayrıştırıp incelemek geremektedir. Bu noktada son yirmi yılda özellikle enerji alanındaki çalışmalarda yaygınca kullanılan ayrıştırma analizi teknikleri oldukça faydalıdır. Ayrıştırma analizi teknikleri sektörel düzeyde etkili olan faktörlerin ayrıştırılmasına dayalı tekniklerdir. Temelde Ekonomi ve istatistikteki endeks sayılar problemine dayalıdır. Fakat daha çok enerji tüketimi ve sera gazı emisyonları gibi çevresel değişkenlerde meydana gelen değişikliklerin anzlizini yapmak için kullanılmaktadır. Ayrıca malzeme akışı ve üretiminde, ulusal enerji verimliliğinin izlenmesinde ve ülkeler arası karşılaştırma yapıl- masında kullanılmaktadır (Granel, 2003:7-9)

1970'li yıllar boyunca enerji şokları sonucu, ayrıştırma analizi sanayi üretimindeki değişimlerin enerji kullanımı ve enerji verimliliği üstündeki değişiklikleri incelemek amacıyla kullanılmıştır. Özellikle ekonomik büyümenin, üretim faktörlerinin sektörler arası değişiminin ve teknolojik değişimin çevresel ve sosyo-ekonomik göstergeler üzerindeki etkisinin belirlenmesi amacıyla kullanılmıştır (Hoekstra ve Van Der Bergh, 2003:40). Bu değişimlerin enerji göstergelerini nasıl etkilediğini anlamak için değişimden önceki ve sonraki gösterge değerleri arasında karşılaştırma yapmak faydalı olacaktır. Ayrıştırma analizinin temeli de burdadır. Buna göre değişime uğrayan bir faktörün temel yıldaki (genellikle $\mathrm{T}_{0}$ olarak sembolize edilir) değeri ile daha sonraki yıl veya yıllardaki değeri (genellikle $\mathrm{T}_{1} . . . . n$ olarak sembolize edilir) karşılaştırıı. Bu noktada araştırmacı isterse baz yıl esaslı modeli (periodwise approach) isterse de zaman serisine dayalı modeli (time series) kullanabilir (Steenhof, 2006:377),

Ayrıştırma analizi iki temel kategoriye ayrıbabilir; yapısal ayrıştırma analizi (SDA) ve endeks ayrıştırma analizi (IDA). SDA girdi çıktı katsayılarına ve girdi çıktı talolarından üretilen nihai mal talebine bağlı iken, girdi çıktı modelinin aksine SDA yöntemi sabit katsayı varsayımı nedeniyle daha az kısıtlanmıştır. Leontief katsayısına haiz olması nedeniyle SDA yönteminde talepteki değişimlerin dolaylı etkisi ölçülebilir. Böylelikle sektörel düzeydeki değişimlerin ardındaki asıl nedenler daha net görülebilir (Jungitz, 2008:17). IDA yöntemi ise sektörel düzeydeki verilere dayanarak sadece dolaysız etkileri ölçer. IDA tekniğinin asıl amacı sektörel düzeyde $V$ değişkeninde meydana gelen değişikliği etkliyen temel neden-sonuç ilişkilerini anlamaktır. Bunun da yolu $V$ değişkeninde meydana gelen değişikliği değişikliğe 
neden olan değişkenler cinsinden ifade etmktir. IDA teknikleri enerji alanında ilk kez 1973 ve 1979 petrol krizlerinden sonra enerji tüketiminde meydana gelen değişiklikleri daha iyi analiz edebilmek amacıyla kullanılmıştır. Basitliği ve esnekliği sayesinde uygulama alnları zamanla genişlemiş̧tir (Granel, 2003:7-9). Örneğin Ang ve Zang tarafından yapılan bir araştırmaya göre 1978-1999 yılları arasında yayımlanan makelelerden yüzden fazlası ayrıştırma analizi ile ilgilidir.

Ayrıştırma analizindeki üretim etkisi, enerji tüketiminde üretim miktarındaki artıştan kaynaklanan etkiyi gösterir. Artan ekonomik çıktı faaliyet etkisini artırır, enerji tüketimindeki büyüme oranını artıcı etki yapar. Enerji tüketimindeki artışa pozitif katkıda bulunur. Eğer çıktı düşerse bu durum enerji talebi artış oranını düşürür ve çıtı etkisi enerji tüketimine negatif olarak etki eder. Örneğin bu etkinin kriz yıllarında azalması beklenir (Zhang, 2003:629-630).

Yoğunluk etkisi, sosyo ekonomik gelişmelerin, teknolojik değişimin ve üretim sistemlerindeki değişikliğin enerji tüketimi üzerindeki etkisidir. Eğer çıktıdaki artış oranı, enerji girdisindeki artış oranından büyükse yoğunluk etkisi azalmaktadır. Daha etkin, verimli üretim tekniklerinin uygulanması, etkin enerji yönetimi, o alt sektörün içinde veya alt sektörler arasında ürün karmasında meydana gelen değişmeler, malzeme ve yakıt girdisinin kalitesinde meydana gelen iyileşmeler yoğunluk etkisini azaltır. Teknolojik değişim hızlandıkça yoğunluk etkisi daha hızlı düşer. Negatif teknolojik ilerleme ise enerji yoğunluğunu arttırır. Enerji üretiminde kapasite kullanım oranının artması yoğunluk etkisini arttırır. Üretim faktörlerinin sektörler arası değişimine neden olan yapısal değişimde de yoğunluk etkisini etkiler. Diğer yandan ülkelerin sanayileşme oranlarının artması, elektrikli alet ve edevatın daha çok kullanılması, elektrikli ev aletlerinin yaygınlaşması yoğunluk etkisini artırıcı etki yapar. Bu yüzden gelişmekte olan ülkelerde enerji yoğunluğu, gelişmiş ülkelere göre daha fazladır. Ayrıca gelişmiş ülkelerde enerji kullanımı, gelişmekte olan ülkelere göre daha verimli ve etkindir. Son olarak enerji fiyatlarının düşük ve istikrarlı seyir izlemesi yapısal ve yoğunluk etkilerini pozitife dönüştürür. Yani negatif eğimli fiyat hareketi, pozitif eğimli yoğunluk etkisine yol açar (Steenhof, 2006:377).

Yapısal etki, enerji tüketimi üzerindeki toplam üretimin sektörel payı içindeki değişimin etkisini ortaya çıkaran etkidir. Örneğin sanayi sektörünün toplam üretim kompozisyonundaki değişemeden kaynaklanan toplam enerji tüketimi değişimidir. Eğer sanayi alt sektörleri içinde, (alt sektör yoksa sanayi sektörünün milli gelir içindeki payı) daha enerji yoğun sektörlerin payı, daha az enerji yoğun sektörlerin payına oranla artarsa, onun yapısal etkisi de artmaktadır ve böyle bir değiş- me toplam enerji talebi üzerinde arttıııı etki yapar ve enerji tüketimindeki büyüme oranı artar. Tam tersine sektör içinde daha az enerji yoğun sektörlerin payı düşerse böyle bir yapısal değişme bu sefer toplam enerji talebi üzerinde düşürücü etki yapacak ve enerji tüketimindeki büyüme oranı azalacaktır (Vehmas, 2010:5).

Ma ve Stern (2007) 1980-2003 yılları arası Çin ekonomisinde enerji yoğunluğundaki değişimi LMDI yöntemiyle incelemiştir. Bu 2000 sonrası dönemde Çin ekonomisi enerji verimliliği hakkında yapılan ilk çalışmadır. Yazarlar Çin ekonomisini, birincil, ikincil ve üçüncül olmak üzere üç temel endüstriye bölmüştür. Analiz sonuçlarına göre teknolojik ilerleme enerji yoğunluğundaki düşüşün en önemli nedenidir. Ikinci olarak endüstriyel ve alt endüstriyel düzeyde meydana gelen yapısal değişimler enerji yoğunluğunu arttırıcı etki yapmıştır. Üçüncü olarak alt sektörler arasında üretim değişimine dayalı yapısal değişme genel enerji verimlilğini düşürmüştür. Dördüncü olarak bazı sektörlerde 2000 yılından beri gerçekte görülen enerji yoğunluğu artışı negatif teknolojik ilerlemeyle açıklanabilir. Son olarak sektörler arası yakıt karmasında meydana gelen değişimlerin enerji yoğunluğundaki değişime katkısının az olduğu belirlenmiştir (Ma ve Stern, 2007:1037-1053).

Cornillie ve Frankhauser (2004) çalışmasında 19921998 yılları için Orta ve Doğu Avrupa ve eski Sovyet bloku ülkeleri için enerji yoğunluklarını incelemiştir. Kömünist blokun çözülmesinden sonra enerji yoğunluları azalmıştır ancak gelinen seviye yeterli değildir. Gelinen seviye hala OECD ülkeleri ortalamasından yüksektir. Ilk grup ülkelerde (Macaristan, Slovenya, Litvanya gibi) hızlı özelleştirme, fiyat liberalizasyonu ve kurumsal yeniden yapılandırma nedeniyle enerji yoğunluğu hızla düşmüştür. Ikinci grup ülkelerde (Polonya, Romanya, Slovakya gibi) milli gelir içinde ağır sanayinin önmli bir yer tutması, ve politik aktörlerin teknolojisi eski sektörlerde yapılması gereken yeniden yapılandırma için zayıf irade göstermesi gibi nedenlerle enerji yoğunluğu hemen hemen aynı kalmıştır fakat ekonominin diğer sektörleri için söz konusu göstergede ilerleme sağlanmıştır. Üçüncü gruptaki ülkeler için geçiş döneminde enerji yoğunluğu, özelleştirmelerin yapılamaması ve sanayi sektöründe yeniden yapılandırmanın gecikmesi nedeniyle daha da artmıştır (Cornillie ve Frankhauser, 2004:283-295).

Greening ve diğerleri (1997) 1970-1992 dönemi 10 OECD ülkesi için enerji yoğunluğunu altı farklı ayrıştırma yöntemiyle incelemiş ve her bir yöntemi ortaya çıkan artık değer, bu değerin değişkenliği ve yöntemin ne derece kolay ugulanabildiği bakımından karşılaştırmıştır. Sonuçlara göre Average Weighting Divisia (AWD) ve Divisia (rolling year simple average) yöntemleri en iyi sonuçları vermiştir. Ampirik bulgu- 
lara göre genel enerji yoğunluğu her bir alt sektörde enerji yoğunluklarında meydana gelen düşüşe bağIı olarak azalmıştır. Norveç gibi bazı ülkelerin daha enerji yoğun sektörlere yönelmeleri genel enerji yoğunluğundaki düşüş trendini olumsuz etkilemişitir. Halbuki Japonya, ABD, Almanya gibi ülkelerin daha az enerji yoğun endüstrilere yönelmeleri enerji yoğunluğundaki düşüşü desteklemişitr. Ayrıca ekonomik büyüme, enerji maliyetleri ve üretim tknikleri enerji yoğunluğu üzerinde önemli derecede etkilidir (Greening vd., 997:375-390).

Steenhof (2006) Çin sanayisi elektrik talebini 1998-2002 yılları arasında Las-Peyers yöntemiyle incelemiştir. Analizden önce yazar sanayi sektörünü üç kısma ayırmıştır; birincil sektörler (P), ikincil sektörler (S-P) ve ikincil imalat sanayi (S-M). Bu sınıflandırma da P'ye dahil sektörler kömür, petrol, doğal gaz gibi birincil enerji kaynakları madenciliği, S-P'ye dahil olan sektörler bu kaynakları hammadde olarak kullanan kimya, maden cevherini ayrıştıran diğer sektörler gibi imalat sanayi ve S-M'ye dahil olan sektörler ise S-P'ye dahil olan sektörlerin çıktılarını nihai ürün olarak üretip tüketicilere sunan sanayi dallarıdır. Toplamsal ayrıtırma yöntemi sonuçlarına göre elektrik tüketimi 1998-2002 yılları arasında çıktı etkisi nedeniyle 579 Twh artmıştır. Fakat talepte meydana gelen 8 Twh 242 Twh'lik azalma enerji yoğunluklarındaki değişime ve yapısal değişime atfedilebilir. Yani hızlı sanayileşmenin elektrik talebinde meydana getirdiği arttırıcı etki verimlilik artışları ve yapısal etki tarafından dengelenmiştir. Üretimdeki artış beraberinde enerji talebinde artışı getirmiştir. Fakat ağır sanayi dallarında enerji verimliliğinde görülen iyileşme alt sektörel düzeyde enerji yoğunluğunu düşürmüştür. Elektrik talebinin artmasındaki en önemli nedenlerden biri yakıt tipinde meydana gelen değişikliklerdir. Doğal gaz ve petrolden elektiğe doğru yöneliş tüm dönemde elektrik talebinde 245 Twh'lik artışa neden olmuştur (Steenhof, 2006:370-384).

Ediger ve Huvaz (2006), 1980-2010 dönemi için Türkiye ekonomisinde sektörel enerji tüketimini LMDI yöntemiyle incelemişlerdir. Buna göre enerji tüketimindeki artışın asıl nedeni üretimdeki artıştır. Kriz yılları hariç çıktı etkisi hep pozitif olmuştur. Ayrıca yapısal etki 15 tane yılda pozitiftir fakat yoğunluk etkisi sadece 8 tane yılda pozitif diğer yıllarda negatif değerler almıştır. Çıktı ve yapısal etki sektörel enerji tüketimini arttırmış, yoğunluk etkisi düşürmüştür. Çıktı etkisi sanayi ve hizmetler sektörlerinde daha belirgin, tarım sektöründe ise zayıftır. Yine çıktı etkisi 1989 öncesinde hizmetler sektöründe sanayi sektörüne göre daha büyüktür. 1989 sonrasında ise sanayi sektöründe daha büyüktür. Yapısal etkiye baktığımızda en çok hizmetler ve tarım sektöründe etkili olduğunu görülür. Yoğunluk etkisi ise hizmetler sektöründe diğer iki sektörde olduğundan daha etkilidir. Ayrıştırma sonuçlarına göre Türkiye ekonomisi 1983-1987, 1990-1993 ve 1995-1997 olmak üzere üç istikrarlı döneme ayrılabilir. Tüm bu dönemlerde çıktı ve yapısal etki pozitifken yoğunluk etkisi negatiftir. Ikinci olarak sektörel enerji tüketimindeki en önemli değişiklikler 1982, 1988-1989 ve bu iki dönem arasında meydana gelen gelmiştir. 1994 ve 1998-2000 dönemlerindeki değişim ise daha çok ekonomik krizlerle ilgilidir. Hızlı şehirleşme, ekonomik büyüme, ve tarım ekonomisinden sanayi toplumana geçişle birlikte sektörel enerji tüketimi de köklü değişikliklere uğramıştır. Toplam birincil enerji tüketimi ekonomik büyüme oranından hızlı artmıştır ve enerji yoğunluğu tepe noktasına ulaşıncaya kadar da böyle gidecektir. Bu yüzden Türkiye ekonomisinde kişi başı gelir 9000 \$'a çıkıncaya kadar bazı yapısal değişikliklere ihtiyaç vardır. Son olarak sanayi sektöründe enerji verimliliği benzer ülkelerle karşılaştırıldığında daha düşüktür dolayısıyla bu konuda bazı iyileştirmelerin yapılması gerekir (Ediger ve Huvaz, 2006:732-745).

\section{METOD}

Literaturde çok çeşitli IDA yöntemleri vardır. Bu çalışmada toplamsal tipteki LMDI yöntemi seçilmiştir. Ang ve Liu (2004), Ang (2004), yaptıkları çalışmalarda daha küçük artık değer vermesi, içinde sıfır değerine sahip olan serileri de işleyebilmesi, toplamsal tutarlılık, kolay uygulanabilmesi ve yorumlanabilmesi nedeniyle LMDI yöntemini diğer yöntemlere tercih edilebileceğini belirtmişlerdir. Bu model sektörel enerji tüketimini enerji yoğunluğu, yapısal değişim ve ekonomik çıktıdaki eğilimlere göre ayrıştırmaktadır. Model basitçe şöyledir;

$\Delta \mathrm{E}_{\text {tot }}=\Delta \mathrm{E}_{\text {prd }}+\Delta \mathrm{E}_{\text {str }}+\Delta \mathrm{E}_{\text {int }}+\Delta \mathrm{E}_{\text {rsd }}$

Bu formülasyona göre 0 yılından $t\left(E_{\text {tot }}\right)$ yılına tplam birincil enerji tüketimindeki değişim, talepteki değişimin nedenleri olarak çıktı etkisi $\left(\mathrm{E}_{\text {prd }}\right)$, yapısal etki $\left(\mathrm{E}_{\text {str }}\right)$, yoğunluk etkisi $\left(E_{\text {int }}\right)$ ve artık değer $\left(E_{r s d}\right)$ şeklinde dört kısma ayrılabilir. Böylelikle her bir sektör için bu etkiler hesaplanabilir. Çıktı, yapısal ve yoğunluk etkileri için sıraısyla şu formüller kullanılır;

$$
\begin{aligned}
& \Delta E_{a c t}=\sum_{i} \frac{E_{i}^{t}-E_{i}^{0}}{\ln E_{i}^{t}-\ln E_{i}^{0}} \ln \left(\frac{Q^{t}}{Q^{0}}\right) \\
& \Delta E_{s t r}=\sum_{i} \frac{E_{i}^{t}-E_{i}^{0}}{\ln E_{i}^{t}-\ln E_{i}^{0}} \ln \left(\frac{S_{i}^{t}}{S_{i}^{0}}\right) \\
& \Delta E_{\mathrm{int}}=\sum_{i} \frac{E_{i}^{t}-E_{i}^{0}}{\ln E_{i}^{t}-\ln E_{i}^{0}} \ln \left(\frac{I_{i}^{t}}{I_{i}^{0}}\right)
\end{aligned}
$$


Burada $E_{i}$ tep cinsinden i sektörü için toplam birincil enerji tüketimini, $Q^{0}$ ve $Q^{t}$ i sektöründeki 0 ve t yıllarındaki milyon som cinsinden toplam üretimini, $S_{i}^{t}$ and $S_{i}^{0}$, i sektörünün 0 ve t yıllarında toplam üretim içindeki paylarını, $I_{i}^{t}$ and $I_{i}^{0}$, i sektörünün 0 ve t yıllarındaki enerji yoğunluklarını Kwh/Milyon som cinsinden verir.

\section{VERi}

Veriler Asya Kalkınma Bankası veri tabanından alınmıştır. Toplam birincil enerji tüketimi olarak, ülkede elektrik üretim ve tüketiminin diğer enerji kaynaklarına göre çok daha fazla kullanılması nedeniyle elektrik tüketimi bazında ve kwh cinsinden alınmıştır. Sektörlerin payları yüzde cinsinden gösterilirken, enerji yoğunlukları elektrik tüketimine bağlı olarak kwh/som cinsinden yani çıktı başı tüktilen elektrik miktarını vermektedir. Ekonomi üç temel sektöre ayrılmıştır; hizmetler, sanayi ve tarım. Hizmetler sektörü ulaştırma, konut ve hizmetler ile diğer enerji tüketimlerini kapsamaktadır. Sanayi sektörü imalat sanayi, madencilik ve elektrik, su gaz sektörlerinden oluşmaktadır. Tarım sektöründe ise alt ayrım yoktur. Çıktı sabit fiyatlarla GSYiH ile gösterldiğinden katma değer kullanmaya gerek yoktur. Son olarak enerji tüketimi içinde çevrim sektörü ve enerji dışı alanlar için kullanılan tüketim hariç tutulmuştur.

\section{AMPIRIK SONUÇLAR}

Bu bölümde daha önce belirtilen eşitlik 2, 3, ve 4 veri setine uygulanmış ve her bir etkinin enerji tüketimini nasıl etkilediği incelenmiştir. Illk olarak 20022011 dönemi için her bir etki hesaplanmış ve sonuçlar tablo 1'de verilmiştir.

Tablo 3: Yıllara Göre Sektörel Enerji Tüketiminin Ayrıştırması (Milyon Kwh)

\begin{tabular}{|c|c|c|c|c|}
\hline \multirow{2}{*}{ Yıllar } & Çıktı & Yoğunluk & Yapısal & \multirow{2}{*}{ Toplam } \\
\cline { 2 - 4 } & Etkisi & Etkisi & Etki & \\
\hline 2003 & 548 & -386 & 354 & 516 \\
\hline 2004 & 671 & -1343 & 227 & -445 \\
\hline 2005 & 237 & -489 & 402 & 151 \\
\hline 2006 & 677 & -837 & 130 & -29 \\
\hline 2007 & 1089 & -904 & 127 & 313 \\
\hline 2008 & 1389 & -1904 & 184 & -330 \\
\hline 2009 & 1410 & -1506 & 62 & -35 \\
\hline 2010 & 217 & -327 & 316 & 206 \\
\hline 2011 & 1079 & 499 & -5 & 1572 \\
\hline Toplam & 7318 & -7196 & 1796 & 1918 \\
\hline
\end{tabular}

Toplamsal ayrıştırma sonuçları yıllık bazda şekil 1 'de tüm dönem itibariyle gösterilmiştir. Ancak sonuçların kolay yorumlanabilmesi için Tablo 3'de özet halde verilmiştir. Tabloya göre 2003 yılında enerji tüketimindeki geçek artış 516 milyon kwh'dir. Bunun 548 milyon kwh'si çıktı etkisi, 354 milyon kwh'si yapısal etki olarak pozitifken yoğunluk etkisi -386 milyon kwh ile negatiftir. Toplamda ise belirtildiği gibi enerji tüketimi 516 milyon kwh artmıştır. 2004 yılında yoğunluk etkisi nedeniyle enerji tüketiminde meydana gelen 1343 milyon kwh'lik tasarruf, diğer iki etkinin arttırıcı etkisini bastırarak, toplam etkinin -445 milyon kwh değer almasına neden olmuştur. Sonuçlara göre sektörel enerji tüketimi tüm dönem itibariyle 1918 milyon kwh artmıştır. Bu artışa en önemli katkı çıktı etkisinden gelmiştir. Yapmış olduğu 7.318 kwh'lik katkı ile toplam artışın \%262'sine kaynaklık etmektedir. Yapısal etki enerji tüketimini 1.796 milyon kwh arttırmış ve toplamda \%93'lük bir katkı yapmıştır. Buna karşıık yoğunluk etkisi azaltıcı rol oynamış ve sektörel enerji tüketime 7.196 milyon kwh'lik düşürücü etki yapmıştır.

Dönemsel olarak enerji tüketimini değerlendirdiğimizde tüketimin artan eğilim içinde gelişim gösterdiğini görürüz. Özellikle 2005 yılından küresek ekonomik krize kadar olan dönemde görülen hızı ekonomik büyümenin etkisiyle çıktı etkisinin değerinin hızla arttığı görülür. Aynı şekilde yoğunk etkisi de 2000'den sonra ekonominin daha fazla dışa açılması ve teknolojik gelişimin hızlanmasıyla enerji tüketimi üzerindeki tasarruf edici etkisi artmıştır. Yapısal etki ise azalan bir trend içinde günümüze gelmiştir. Şekil 1'de çıktı etkisi, yapısal etki ve yoğunluk etkisi yıllık bazda verilmiştir.

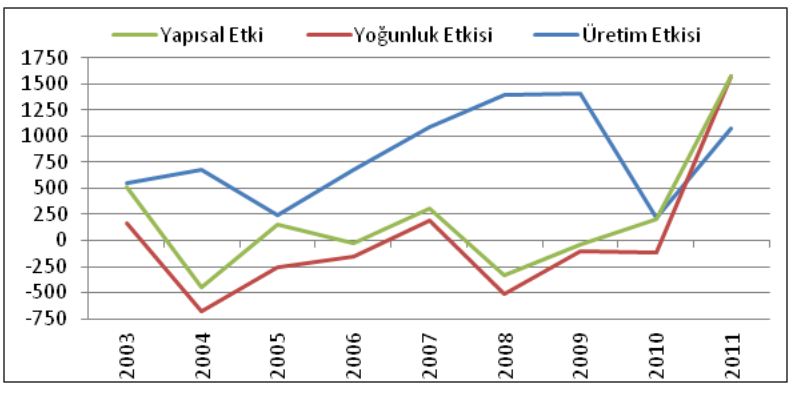

Şekil 2: Kırgızistan Ekonomisi Toplam Birincil Enerji Tüketiminin Ayrıştırması

Şekil 2'de görüldüğü gibi toplam tüketimdeki değişime en büyük katkı çıktı etkisinden gelmiştir. Fakat yoğunluk etkisinin gücü çıktı etkisine yakındır. Yoğunluk etkisi tüketimi düşürücü etki yapmıştır. Yapısal etkinin katkısı ise sınırlı olmuştur, çünkü ülke geçiş döneminden itibaren tarım ve hayvancılığın ağılıklı olduğu ekonomik yapıdan sanayi toplumuna ve bilgi toplumuna geçiş için çabalamaktadır ve kalkınma yolunda gelmiş olduğu nokta itibariyle hizmetler sektörünün milli gelir içindeki payı gelişmiş ülkelerdeki ka- 
dar yüksek değildir. Ayrıca ülke ekonomisinde enerji verimliliği ve etkin enerji kullanımı yeterli seviyede değildir. Dolayısıyla enerji tüketimindeki artışın asıl kaynağı çıktı etkisidir.

Enerji tüketimindeki artışa en büyük katkı çıktı etkisinden kaynaklanmıştır. 2002-2011 döneminde hep pozitif bölgede seyretmiştir. Ikinci olarak çıktı etkisinin seyri 2006-2009 arasındaki ortalama \%20'lik ekonomik büyüme nedeniyle hızla artmış, ancak son yaşanan küresel finansal krizin ekonomik büyümeyi yavaşlatmasıyla 2009 yılında 1.410 milyon kwh'den 2010 yılında 217 milyon kwh'ye düşmüştür.

Yapısal etki, tıpkı çıktı etkisi gibi pozitiftir ancak büyüklük olarak çıktı etkisinden küçüktür. Tüm dönem boyunca azalan bir trend izlemiştir. Çıktı etkisi ile birlikte enerji tüketimini artııı etkide bulunmuştur. Sovyet dönemi boyunca blok içindeki intisaslaşmada kendine biçilen rol nedeniyle tarım ve hayvancilık ülkesi olan Kırgızistan'ın sosyo ekonomik gelişmişlik seviyesi hep geri kalmıştır.

Sovyet blokunun dağılmasıyla gelen bağımsızlık ve serbest piyasaya geçiş süreci ülkeyi ilk yıllarda tam tersine daha da geriye götürmüş ve 1991-1995 arası ekonomi yıllık ortalama \%12 küçülmüştür. Bu nedenlerle tarımın milli gelir içindeki payı oldukça fazladır ve kullanılan tarım teknikleri modern değildir. Sanayinin gelişimi sınırlı olmuş milli gelir içindeki payı düşük kalmıştır. Zaten sanayi içinde de madencilik ön plana çıkmış diğer sanayi dalları yeterince gelişmemiştir. Bu yüzden Kırgızistan sanayisini güçlendirecek politikalar izlemiş, tarım toplumundan sanayi toplumuna geçişi hızlandırmaya çalışmıştır. Bu politikaların sonucunda da sanayinin milli gelir içindeki payı artmış, tarımın azalmıştır. Işte böyle bir yapısal değişim yapısal etkinin enerji tüketimini arttırıcı etkide bulunmasına neden olmuştur. Bu iki etkinin tersine yoğunluk etkisi çoğunlukla negatif bölgede seyretmiş ve enerji tüketimini düşürücü etkide bulunmuştur. Özellikle hızlı ekonomik büyüme, ekonominin dışa açılması (1994 yılından 2011 yılına ihrcatın ve ithalatın milli gelire oranı sırasıyla \%30'dan \%39'a ve \%38'den \%67'ye çıkmıştır), dış rekabet, yeni teknoloji girişleri gibi nedenlerle düşme eğilimi içine girmiştir.
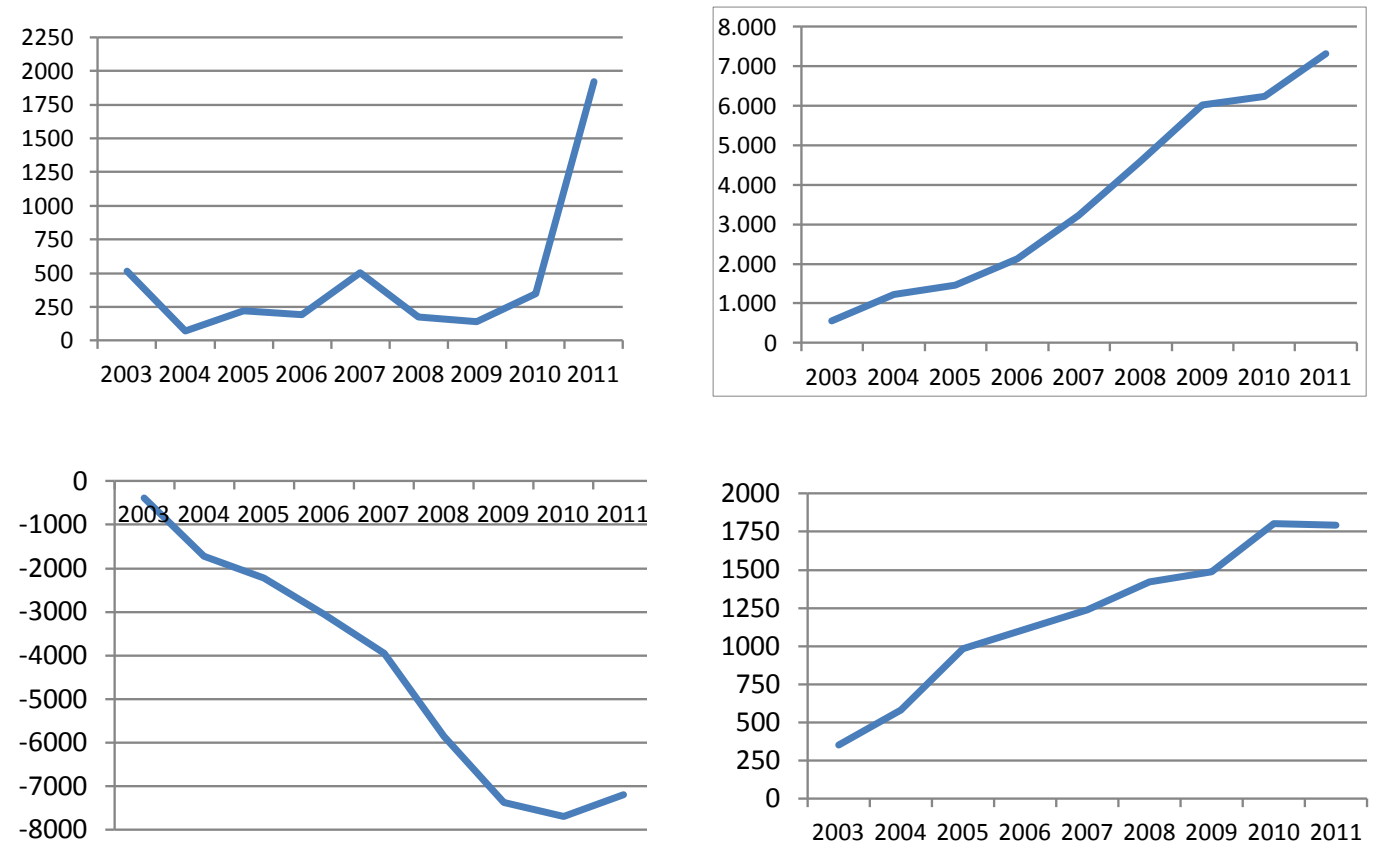

Şekil 3: Enerji Tüketimindeki Kümülatif Değişim (kwh)

Analiz sonuçları şekil 3'te toplam etki, çıktı etkisi, yapısal etki ve yoğunluk etkisi kümülatif olarak verilmiştir. Ilk olarak toplam etkiye bakıldığında 2003-2010 yılları arasında yatay bir seyir izlemiş, 2011 yılında ise hızlı bir artış göstermiştir. Bunda çıktı etkisinin enerji tüketimini arttırıcı gücünün, yoğunluk etkisinin düşürücü etkisi tarafından dengelenmesi etkili olmuştur.

Yoğunluk etkisi tüm dönem boyunca enerji tüketimini düşürücü etki yaparken sadece 2011 yılında 499 milyon kwh arttırıcı etki yapmıştır. Bunda hizmetler 
sektöründeki enerji yoğunluğunun artması etkili olmuştur. Söz konusu yılda sektör içinde enerji tüketimi $\% 27$ artarken üretim artışı \%13'te kalmıştır. Ayrıştırma analizi sonuçlarına göre toplam etki 2004, 2006, 2008 ve 2009 yıllarında negatif, diğer yıllar pozitif değerler almıştır. Negatif değer aldığı yıllarda yoğunluk etkisinin düşürücü gücü, diğer iki etkiye nazaran daha baskın çıkmıştır. Sonuç olarak toplamda enerji tüketimi 2002-2011 arası 1.918 milyon kwh artmıştır. Ilk yıl 516 milyon kwh artış gösteren toplam etki 2004 yılında yoğunluk etkisi nedeniyle enerji tüketiminde meydana gelen 1.343 milyon kwh'lik tasrrufun etkisiyle 445 milyon kwh azalmış ve toplamdaki artış 71 milyon wh olmuştur. 2005 yılında 222 milyon kwh'ye çıkan toplam değişim 2006 yılında tekrar azlarak 192 kwh'ye düşmüştür. Bu şekilde dalgalı seyrine devam eden toplam etki 2011 yılında kümülatif olarak 1918 milyon kwh'lik büyüklüğe ulaşmıştır. Çıktı etkisi ise toplam etkiden farklı olarak düzgün artan bir seyir izlemiştir. Buna dönem boyunca ortalama \%13 olarak gerçekleşen istikrarlı ekonomik büyüme etkili olmuştur.

Çıktı etkisi toplamda 7.318 milyon kwh'lik artış yaratmıştır. Yoğunluk etkisine kümülatif olarak bakıldığında istikrarlı şekilde azalmış ve enerji tüketiminde 7.196 milyon kwh'lik tasarruf sağlamıştır. Şekil 2'de görüldüğü gibi 2011 hariç tüm yıllarda düşüş göstermiştir. Yapısal etki benzer şekilde istikrarlı olarak tüm dönem boyunca enerj tüketimini arttırıcı etkide bulunmuş ve kümülatif olarak, tüm dönem boyunca ortalama \%25 artışla 2011 yılında 1.796 milyon kwh'lik büyüklüğe ulaşmıştır. Sonuç olarak ayrıştırma analizi kümülatif sonuçlarına göre, tüm dönem boyunca Kırgızistan ekonomisi enerji tüketiminde görülen artışın en önemli kaynağı çıktı etkisidir. Yapısal etki kısmen etkili olmuş, yoğunluk etkisi ise düşürücü etki yapmıştır.

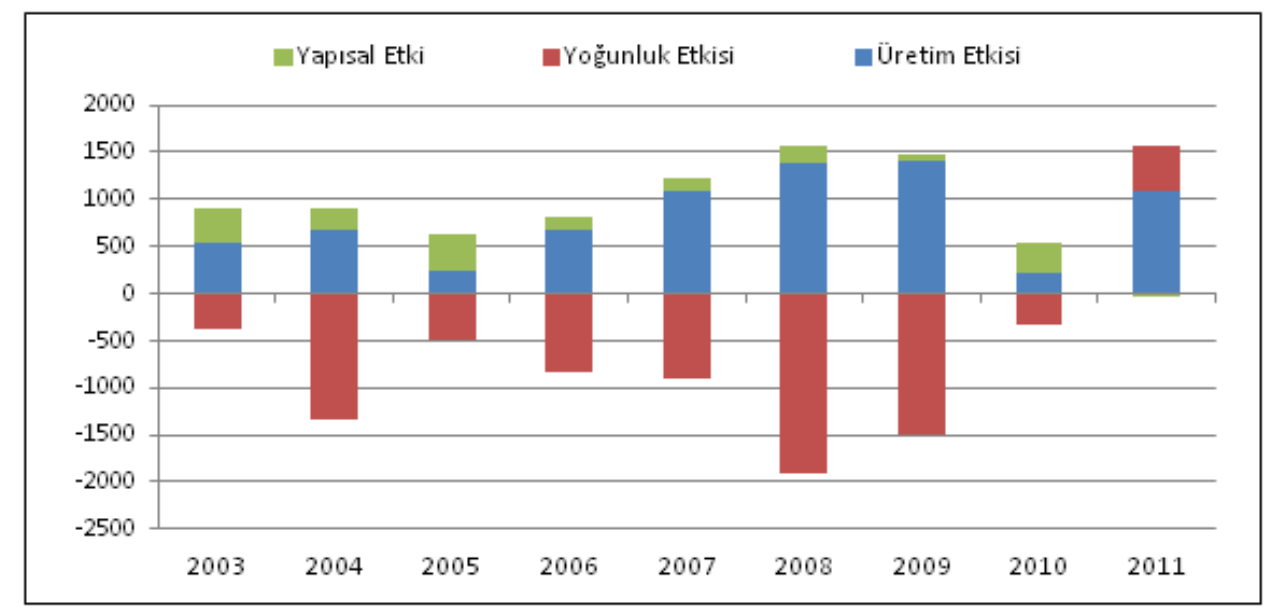

Şekil 4: Kırgızistan Ekonomisi Birincil Enerji Tüketimi Ayrıştırma Analizi (Mkwh)

Şekil 4'te daha önce Tablo 1'de belirtilen veriler grafik olarak düzenlenmiştir. Görüldüğü gibi çıtı ve yapısal etki pozitif bölgede yer alarak enerji tüketimini arttırıcı etki yaparlarken, yoğunluk etkisi 2011 hariç negatif bölgede yer alarak enerji tüketimini azaltı$\mathrm{Cl}$ etki yapmıştır. Yapısal etki ise diğer iki etkiye göre enerji tüketimindeki değişimi daha az etkilemiştir.

Sovyet dönemindeki ithal ikameci politikalar, ekonomideki koruyuculuk anlayışı, merkezi planlama dahilindeki hükümet müdahaleleri, ekonomik faaliyetlerin sübvansiyonlarla desteklenmesi neticesinde enerji verimliliği ikinci plana itilmiş, askeri harcamalar ön plana alınarak prodüktif yatırımlar azalmış, üretim miktarını arttırmak önem kazanmıştır. Bağımsızlık sonrası geçiş süreci ile birlikte serbest piyasa ekonomisine geçiş, ihracatın-ithalatın artması, ekonomik büyümenin hızlanması, ekonominin dış rekabete açılması ve ar-ge harcamalarının artması, Kırgız ekonomisinde enerji verimliliğine ve enerji koruma politikalarına daha çok önem verilmesine neden olmuştur. Bu yeni dönemde ekonomi daha rekabetçi ve daha piyasa odaklıdır. Işte bu yeni ekonomik yapıda enerji yoğunluğu kademeli olarak düşmeye başlamıştır. Ayrıca rekabetçi piyasa yapısında firmaların daha kar odaklı davranması ve ekonomik büyümenin hızlanması da enerji yoğunluğunun azalmasında etkili olduğu söylenebilir. Tüm bu gelişmeler sonucunda yoğunluk etkisi enerji tüketimini toplamda 7.196 milyon kwh düşürmüştür. 
Tablo 4: Kırgızistan Ekonomisinde Sektörel Enerji Tüketimine Her Bir Etkinin Katkısı(2002-2011, Mkwh)

\begin{tabular}{|l|c|c|c|c|}
\hline & Hizmetler & Sanayi & Tarım & Toplam \\
\hline Çıktı Etkisi & 6252,1 & 948,4 & 117,9 & 7318 \\
\hline Yoğunluk Etkisi & $-6056,3$ & $-792,2$ & $-347,2$ & -7196 \\
\hline Yapısal Etki & 1772,5 & 101 & $-77,9$ & 1796 \\
\hline Toplam & 1968,3 & 257,3 & $-307,1$ & 1918 \\
\hline
\end{tabular}

Yukarıda yapılan analizler sektörel ayrıştırmanın tam ayrıntılı analizini vermemektedir. Ayrıştırmayı sektörel bazda (tarım, hizmetler ve sanayi) ve her bir etki bazında karşılıklı olarak değerlendirildiğinde Tablo 4'de görüldüğü gibi çıktı etkisi her bir sektör için pozitif çıkmıştır. Yani tüm sektörlerde üretimin artması kullanılan enerji miktarını arttırmıştır. Görüldüğü gibi çıktı etkisi tüm dönemde enerji tüketimini hizmetler sektöründe 6.252,1 Mkwh, sanayi sektöründe 948,4 Mkwh ve tarım sektöründe 117,9 Mkwh arttırmıştır.
Yapısal etki ise tarım sektörü hariç enerji tüketimini arttırıcı etki yapmıştır. Yapısal etki enerji tüketimini hizmetler sektöründe $1.772,5 \mathrm{Mkwh}$ ve sanayi sektründe 101 kwh arttırıken, tarım sektöründe 77,9 Mkwh tasarruf sağlamıştır. Tarımın milli gelir içindeki payının yıldan yıla azalması bu şekilde bir yapısal dönüşüme yol açmıştır. Yapısal ve çıktı etkisinin aksine, yoğunluk etkisi tüm sektörlerde enerji tüketimini düşürmüştür. Tablo 4'de de görüldüğü gibi enerji tüketimini hizmetler sektöründe 6053,3 kwh, sanayi sektöründe 792,2 Mkwh ve tarım sektöründe ise 347,2 Mkwh düşürmüştür. 2002-2011 döneminde tarım sanayi ve hizmetler sektörlerinde sabit fiyatlarla milli gelir sırasıyla \%49, \%236 ve \%341 artarken, kulanılan enerji tüketimleri tarım sektöründe $\% 78$ düşmüş, hizmetler ve sanayi sektörlerinde sırasıyla $\% 40$ ve $\% 33$ artmıştır. Bu verilerde göstermektedir ki yoğunluk etkisi tüm sektörlerde enerji tüketiminde 7196 Mkwh'lik tasarruf sağlamıştır.

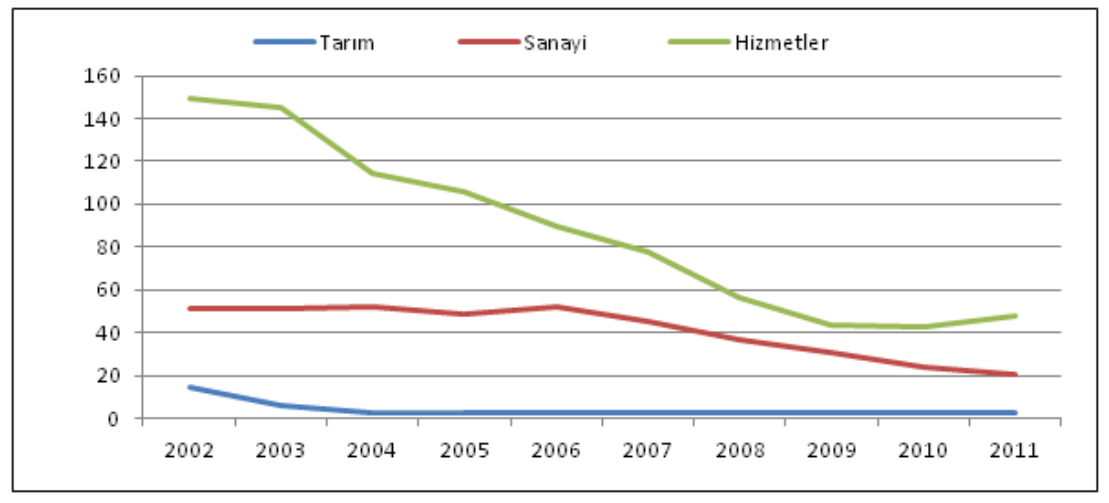

Şekil 5: Kırgızistan Ekonomisi Sektörel Enerji Yoğunluğu (kwh/som)

Şekil 5'te de sektörel enerji yoğunluğu 2002-2011 yılları için kwh/som cinsinden verilmiştir. Illk olarak hizmetler sektöründe enerji yoğunluğunun düzgün bir trend içinde azaldığını ancak yaşanan son küresel finansal kriz sürecinde bu azalmanın yatay bir seyir aldığı görülmektedir. Rakamsal olarak belirtmek gerekirse 2002 yılında hizmetler sektöründe 1000 som değerinde katma değer yaratmak için yaklaşık 150 kwh'lik enerji kullanılıyorken günümüzde 50 kwh civarına düşmüştür.

1991-2000 yılları arasında geçiş sürecinin önemli kısmını tamamlayan Kırgız ekonomisi, yeniden yapılandırma çalışmaları altında serbest ticaret rejimini kabul etmiş, ülke daha fazla dışa açılmış, özelleştirme çalışmalarını devam ettirmiş, liberal ekonomik reformlar uygulamıştır. Bu gelişmelerin etkisiyle ülkede turizm, ulaştırma, ticaret ve iletişim sektörlerinde sovyet döneminden kalma eski teknolojiler yerini yavaş yavaş yeni teknolojilere bırakmaya başlamış, söz konusu sektörlerde verimlilik ve rekabet artmıştır. Sanayi sektöründe ise 2002 yılında 1000 som'luk katma değer için 51,4 kwh enerji harcanı- yorken 2011'de bu miktar 20,3 kwh'ye düşmüştür. 20022006 yılları arasında yatay bir seyir izleyen değer 2006 yılından sonra sektördeki hızlı çıktı artşına bağlı olarak düşmeye başlamıştır. ülke ekonomisinde madencilik ve metalurji sektörleri önemli yer tutmaktadır. Özellikle Kumtor altın madeni gerek üretimi, gerekse yaptığı ihracatla ülke Gayri Safi Yurt İçi Hâsıla'sının \%6'sını, ihracatının \%37'sini, sanayi sektörünün ise \%38'ini oluşturmaktadır. 2006 yılında yaşanan kaza ve sonrası dönemde yaşanan toparlanma ile ilgili sektör ve ona bağlı diğer sektörlerde üretim artışı ile birlikte enerji yoğunluğu değerlerindeki düşüş hızlanmıştır.

Tarım sektöründe ise aynı değerler sırasıyla 2002 yılında 15 kwh'den 2011 yılında 2,1 kwh'ye düşmüştür. Illk yıllarda hızla düşüş gösteren tarım sektörü enerji yoğunluğu, sonraki yıllarda düşüş ivmesini kaybetmiş ve 2 kwh civarında dengeye oturmuştur. Kırgızistan'da tarımsal üretim önemli değişiklikler geçirmiştir. Bağımsızlığının ilk yıllarında geçiş sürecinde Sovyet döneminden kalma zirai makine-ekipman parçalarının temininde zorlanmaya başlamış, 
tarımsal girdi akışı kesilmiştir. Devlet, gerekli gübre ve ekipman parçalarını diğer ülkelerden sağlamaya çalışmakla birlikte, bunların Sovyet dönemine göre çok daha pahalı olması sebebiyle beklenen sonuç alınamamıştır. Yatırımların eksikliği ise yeni tarımsal teknolojilerin uygulanmaması nedeniyle sektörel büyüme geçiş sürecinin ilk yıllarında negatif olmuş, zirai üretim ve verimlilik düşmüştür.
Ancak 2000'li yıllarla birlikte ekonomideki yapısal dönüşüm neticesinde, sektöre yeni teknoloji girişi artmış, tarımsal alet ve ekipmanlar yenilenmiş, sulama sistemleri yenilenmiş, toprak mülkiyet sistemi geliştirilmiş ve sektöre yeni teşvikler getirilmiştir. Böylelikle sektörel enerji yoğunluğu 2000'li yıllarda düşük seyrini devam ettirmiştir (DEIK, 2012:11).

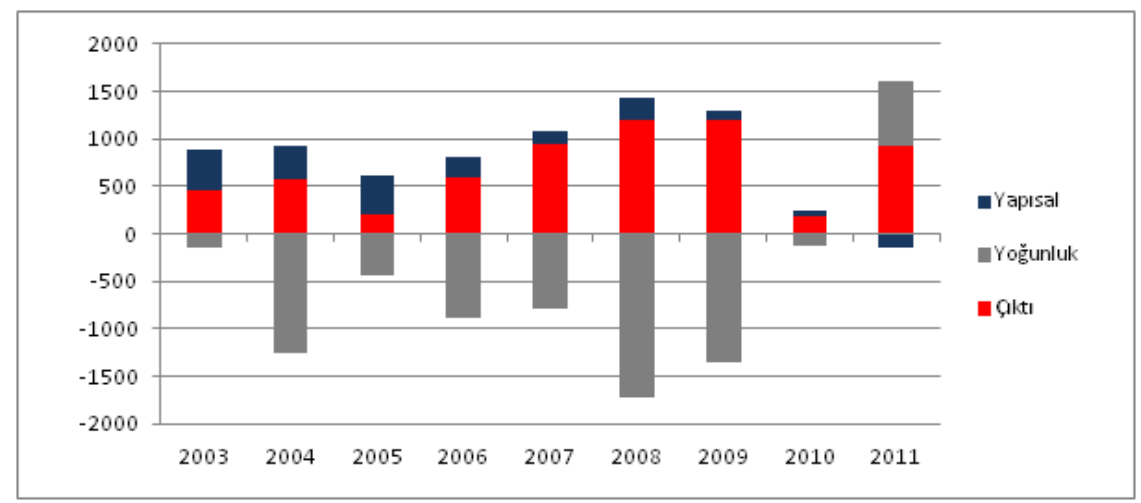

Şekil 6: Hizmetler Sektöründe Ayrıştırma Analizi Sonuçları (Mkwh)

Şekil 6'da sadece hizmetler sektörü için ayrıştırma analizi sonuçları verilmiştir. Buna göre Kırgızistan ekonomisinin hizmetler sektörü enerji tüketimindeki artışta en önemli faktör çıktı etkisidir. Tüm periyotta çıktı etkisi 2004, 2006 ve 2007 yıllarında yoğunluk etkisinin tasarruf edici gücü nedeniyle negatif, diğer yıllarda ise çıktı ve yapısal etkinin enerji tüketimini arttıcı etkisi nedeniyle pozitiftir. Tüm dönem itibariyle çıktı etkisi ve yapısal etki enerji tüketimini sırasıyla $6.252,1 \mathrm{Mkwh}$ ve $1.772,5 \mathrm{Mkwh}$ arttırmış, yapısal etki ise 6.056,3 kwh düşürmüştür.

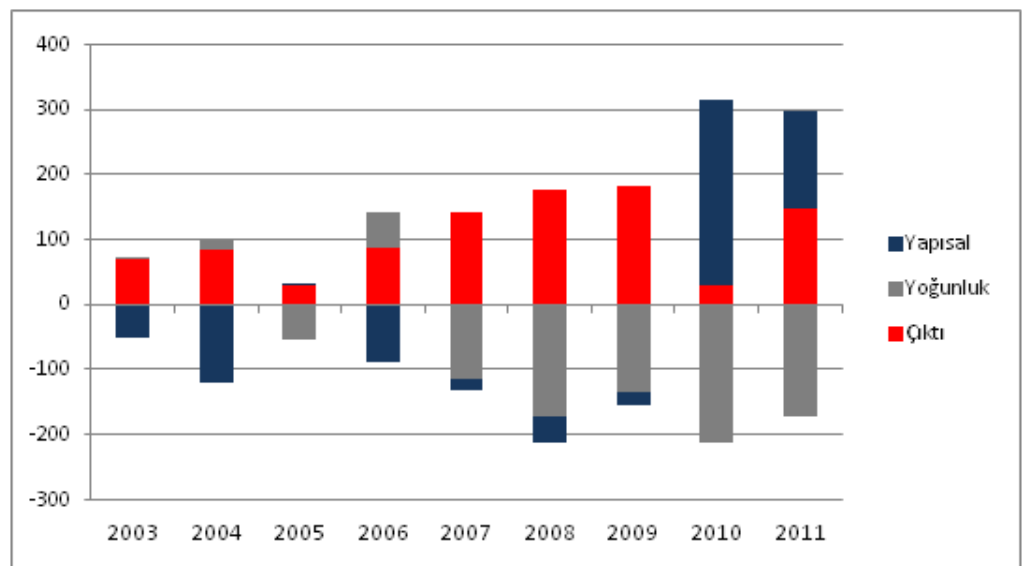

Şekil 7: Sanayi Sektörü Ayrıştırma Sonuçları (Mkwh)

Kırgızistan ekonomisi için sanayi sektöründeki çıktı, yapısal ve yoğunluk etkisi yıllar itibariyle şekil 7'de gösterilmiştir. Sanayi sektöründe 2004 yılında yapısal etki (-119,3 Mkwh) nedeniyle, 2005 ve 2008 yıllarında ise yoğunluk etkisi (-114,7 Mkwh ve 172,9 Mkwh) nedeniyle enerji tüketimi düşmüştür. Diğer yıllarda ise sanayi sektörü üretim artışının enerji tüketimini arttırması nedeniyle toplam etki pozitif olmuştur. Şekilde görüldüğü gibi yoğunluk etkisi sanayi sektöründe 2003, 2004 ve 2006 hariç hep negatif değerler alarak enerji tüketiminde 792,2 milyon kwh tasarruf edici etki yaratmıştır. Aynı şekilde yapısal etki de son yaşanan küresel finansal krize kadar sanayi sektörü enerji tüketimini düşürücü etki yapmış, krizin etkiilerinin geçmesi ve sanayi sektörünün milli gelir içindeki payının artmasıyla birlikte yapısal etki pozitife dönmüştür. Tüm dönem boyunca sanayi sektöründeki yapısal etki enerji tüketimini 101 milyon kwh arttırmıştır. Çıktı etkisi ise sanayi sektöründeki üretim artışına bağıı olarak tüm yıllar pozitif seyretmiş ve enerji tüketimini toplamda 948,4 milyon kwh arttırmıştır. 


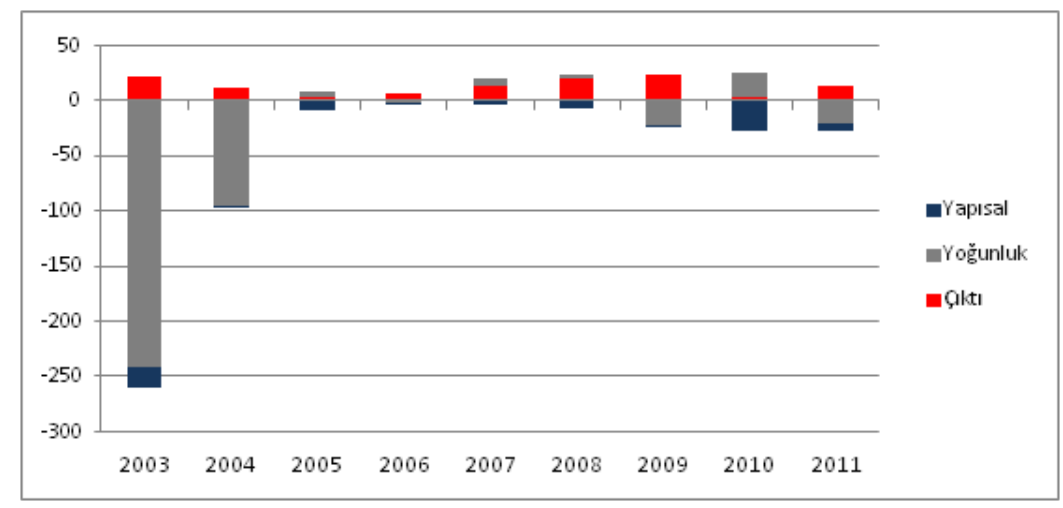

Şekil 8: Tarım Sektörü Ayrıştırma Analizi Sonuçları (Tep)

Son olarak Tarım sektörüne baktığımızda şekil 8'de görüldüğü gibi sanayi ve hizmetler sektöründen farklı bir yapı arz etmektedir. Milli gelir ve birincil enerji tüketimi içindeki sınılı payı dolayısıyla her üç etkinin büyüklüğü, diğer iki sektörde olduğundan daha azdır. Net olarak bakıldığında tüm periyot dahilinde tarım sektöründe enerji tüketimi toplam 307 milyon kwh azalmıştır.

İlk olarak çıktı etkisi tüm yıllarda pozitif değer alarak sektörel enerji tüketimini toplamda 117,9 milyon kwh arttırmıştır. Yoğunluk etkisi ise tam tersine 2005, 2007, 2008 ve 2010 yılları hariç pozitif değerler almış ve tüm dönem boyunca tarım sektörü enerji tüketiminde 347,2 milyon kwh enerji tasarrufu sağlamıştır. Yapısal etkiye bakılırsa tarım sektörünün milli gelir içindeki payının yıldan ıla azalmasına bağlı olarak tüm yıllar boyunca negatif değerler almış ve sektörel enerji tüketiminde 77,9 milyon kwh düşürücü etki yapmıştır.

\section{SONUÇ}

Kırgızistan ekonomisi geçiş süreci ve sonrasında yaşadığı siyasal ve toplumsal dalgalanmaların, karışıklıkların üstesinden gelmeyi büyük ölçüde başarmış, yapılan son seçimlerden sonra demokratik kültür ve bilincin, ekonomik politikalarında istikrara verilen önemin değerini kavramış görünmektedir. Bu süreçte ekonomik kurumlar ve alt yapıda değişikliğe uğramış, ülke tarım ve hayvancılığın ağırlıkta olduğu tarım ülkesi görünümünden hızla uzaklaşmaya başlamıştır. Bu süreçte, yer altı zenginliklerinin ve doğal şartlarında etkisiyle, belirlenen liberal ekonomi politikaları doğrultusunda ekonomide tarımın ağılığı azalmaya sanayi ve hizmetler sektörünün payı artmaya başlamış, ihracat ve ithalat artışı ile beraber ülke daha fazla dışa ve dış rekabete açılmış, ülkede tüm sektörlerde Sovyet döneminden kalma eski teknoloji terk edilip yerine yeni teknolojiler ikame edilmiş ve daha kalifiye işgücü yetiştirilmeye başlanmıştır. Bu yapısal dönü- şümler neticesinde enerji tüketimi de artmaya başlamış, enerji tüketiminde üretim kaynaklı tüketim artışı ön sıraya yerleşmiştir.

Tarım sektörünün milli gelir içindeki payının azalıp diğer iki ana sektörün payının artması beklenen bir süreçtir. Tarım sektörünün milli gelir içindeki payının azalması ile beraber bu sektör kaynaklı yapısal etki negatif gerçekleşmiştir. Ancak son küresel finansal krize kadar sanayi sektörü kaynaklı yapısal etki enerji tüketiminde düşüş yaratırken, kriz sonrasında arttır$\mathrm{Cl}$ etki yaratmıştır. Hizmetler sektörü ise toplamda pozitif yapısal etkiye neden olmuştur. Işte bu etkiler neticesinde yapısal etki hizmetler sektörü nedeniyle enerji tüketimini arttırıcı etki yaratmıştır. Dolayısıyla hizmetler ve sanayi sektörleri için enerji tasarrufu sağlayan yeni teknolojilerin oranı arttırılmalıdır.

Son olarak ülkede teknolojik alt yapının yenilenmesi, daha etkin, verimli üretim tekniklerinin uygulanmaya başlanması, enerji verimliliğinin artması ve etkin enerji yönetimi gibi nedenlerle yoğunluk etkisi enerji tüketiminde tasrrufa yol açmıştır.

Çalışma ülkede elektrik enerjisinin önemi nedeniyle birincil enerji tüketimi olarak elektrik enerjisi üretim ve tüketimini baz almıştır. Kırgızistan ekonomisinde elektrik enerjisi piyasası diğer kaynaklara göre ayrı bir yere sahiptir, çünkü elektrik enerjisi ülkede hem günlük hayatın her alanında yaygınlaşmış olması, sanayi sektöründe temel girdi olması ve depo edilemez olması nedeniyle önemlidir. Elektrik tüketimi günümüzde önemli gelişmişlik göstergelerinden biridir. Bu yüzden üretimden iletim ve dağıtımına kadar merkezi planlama gerekir. Yapılacak planlara göre üretim merkezlerinin ve yeni iletim hatlarının kurulması, gerekli teknolojik iyileştirmelerin yapılması maliyetlerin düşürülmesi gerekir. Bunlar içinde büyük ölçekli yatırımlar şarttır. Bu noktada sadece kamu değil, özel sektörün dinamizminden de yararlanılmalıdır. Kamu yatırımlarının yetersiz kaldığı noktalarda milli çıkarlar 
inmal edilmemek kaydıyla yerli ve yabancı yatırımlar teşvik edilmelidir. Özelleştirme faaliyetleri kamu yararı ve milli çıkarlar mümkün olduğu kadar zarar görmeden yürütülmelidir. Özellikle güvenilir ve düşük fiyatlı elektrik enerjisi arzının sağlanması için mevcut iletim ve dağıtım hatlarının iyileştirilmeli, kayıp ve kaçakların azaltılmalı, üretimde doğal gaz yerine HES'ler ve diğer yerli kaynaklara önem verilmelidir.

\section{KAYNAKLAR}

Ang, B.W. ve Liu, F.L. (2004) A "Generalized Fischer Index Approach to Energy Decomposition Analysis" Energy Economics, 26:757-763.

Ang, B.W. (2004) "Decomposition Analysis for Policy Making in Energy: Which Is Preferred Method?" Energy Policy, 32(9):1131-1139.

Asian Development Bank (2004) "Fact Sheet 2012" http://www.adb.org/publications/kyrgyz-republic-factsheet, (20.04. 2013).

Cornillie, J. ve Frankhauser, S. (2004) "The Energy Intensity of Transition Countries" Energy Economics, 26:283-295.

DEIK (2012) "Kırgızistan Ülke Bülteni” Dış Ekonomik İlişkiler Kurulu, Ankara.

Ediger, V. ve Huvaz, Ö. (2006) "Examining the Sectoral Energy Use in Turkish Economy (1980-2000) With the Help of Decomposition Analysis" Energy Conversation and Management, 47:732-745.

Egeli, H.A. ve Emsen, Ö.S. (2002) "Geçiş Sürecinde Kırgızistan Ekonomisi” Sosyal Bilimciler Dergisi, 103-116.

Granel, F. (2003) "A Comperative Analysis of Index Decomposition Methods" Master Thesis, National University of Singapore, Singapore, Deparment of Industrial and System Engineering.

Greening, L., William, B., Schipper, L. ve Khrushch, M. (1997) "Comparison of Six Decomposition Methods: Application to Aggregate Energy Intensity for Manufacturing in 10 OECD Countries" Energy Economic, 19:375-390.
Hoekstra, R. ve Van Der Bergh, J. (2003) "Comparing Structural and Index Decomposition Analysis" Energy Economics, 25:39-64.

Jungitz, A. (20.06.2013) "Decomposition Analysis of Greenhouse Gas Emissions, Energy and Material Inputs in Germany" http://www.petre.org.uk/papers.htm

Kyrgyzstan Country Report, Transformation Index BTI 2012(2013) http://www.bti-project.org/country-reports/pse/kgz. (20.04.2013)

Ma, C. ve Stern, D. (2007) "China’sChanging Energy Intensity Trend, A Decomposition Analysis" Energy Economics, 30:1037-1053.

Mazat, N. ve Serrano, F. (2009) "An Analysis of Soviet Economic Growth From the 1950's to the Collapse of USSR" Centro Sraffa Working Paper Series.

Ramazanoğlu, G. ve Acar, İ. (2003) ) "Bir Geçiş Ekonomisi Örneği Olarak Kırgızistan: Siyasi Ekonomik ve Toplumsal Yanaşımlar" Review of Social, Economic and Business Studies, 7/8:385-402.

Steenhof, P. (2006) "Decomposition of Electricity Demand in China's Industrial Sector" Energy Economics, 28:370-384.

Vehmas, J. (2010) "AB ve Türkiye'de CO2 Etkinliği Gelişimi” Finlandiya Geleceği Araştırma Merkezi Turku Ekonomi ve İş İdaresi Okulu.

Zhang, Z.X. (2003) "Why Did the Energy Intensity Fall in China's Industrial Sector in 1990's; The Relative Importance of Structural Change and Intensity Change" Energy Economics, 25:625-638. 
